\title{
Prayer in Islamic Thought and Practice
}

Marion Holmes Katz

New York: Cambridge University Press, 2013. 243 pages.

Prayer in Islamic Thought and Practice, part of the "Themes in Islamic History" series, is divided into an introduction, five chapters, and a short conclusion. In the introduction, the author focuses on salāt, the five canonical daily prayers. The book offers a historical study based mainly on pre-modern Arabic sources from the ninth to the sixteenth century, which is supplemented by sec- 
ondary and modern non-Arabic sources to cover major changes in the practice or interpretation of salät (p. 2). Katz quotes the views of pre-modern and modern western observers, thereby showing their sympathy and admiration for the concentration, devotion, seriousness, reverence, regularity, egalitarianism, and inclusiveness associated with it.

In Chapter 1, "Canonical Prayer and Supplication, Development, and Rules," Katz traces the etymology of the term's linguistic origin, historic significance, and pre-Islamic meaning. She quotes Q. 31:17 to show that it was not used exclusively in reference to monotheism or the Abrahamic faiths. Salät is explained both in terms of the prayer's religious content and physical postures. Its validity is discussed and shown to be dependent upon several conditions, such as the knowledge of specific times, ritual purity, orientation to Makkah, and intention. The prayer components (arkān) are also dealt with in detail.

From the daily canonical prayers, Katz moves to the supererogatory ones (nawäfil) and others: tahajjud, mosque greetings, istikhārah (for decisions), șalāt al-hājah (in times of distress), șalāt al-tawbā (repentance), tarāwīh (p. 26), and the plague prayer (p. 38). There are also prayers for safe travel (safar) and a tasbih prayer, which are not mentioned and would have completed the otherwise thorough list. Katz contrasts ritual prayer with the freer and less regulated supplications ( $\left.d u^{\prime} a h\right)$ in the chapter's second part, which deals with petitionary prayers or supplications performed by the prophets Job, Jonah, Zakariya, and Muhammad. She mentions the favorable times and places for supplications, such as the last ten days of Ramadan, laylat al-qadr, Friday, or in Makkah and Madinah.

In chapter 2, "Valid Prayer and Ideal Prayer," the author addresses the rules of validity for prayer, from intent (niya) to distinguish the ritual prayer from other merely routine activities, and to identify it as 'ibādah (act of worship) rather than 'adah (purely customary action) (p. 45) to reverence (khushī) and concentration (hudūur al-qalb). She also explains how it affects and cultivates such emotions as reverence, humility, glorification, awe, obedience (t $\left.\bar{a}^{\prime} a h\right)$, submissiveness, comprehension (tafahhum), hope, shame, and love, as well as Sufi views of prayer being joy, comfort, and ecstasy, but also result in weeping. Prostration is again dealt with (p. 85) in a slight repetition from the first chapter.

In chapter 3, "Interpretive Models: What Is Șalāt and What Does it Do?" this practice's underlying rational objectives and its role as a spiritual exercise are analyzed. Interpretations by a wide spectrum of Muslim authors from various sectarian affiliations and schools of jurisprudence are quoted. The model of a royal audience, a reverent fearful subject standing in the awesome 
and compassionate presence of a great king (al-malik), are contrasted to prayer as an intimate conversation (munājāt) or a two-sided dialogue. The tashahhud ending the prayer before the taslim is presented as a conversation from the Prophet's Night Journey (isrā'wa al-mi 'rāj) (pp. 95-98). Prayer as an exercise of self-discipline, a periodic reaffirmation of the individual's covenantal commitment to God, as a way to exhort the lower self (nafs) and mold human character through repetition are noted, along with the philosophical view of its apparent (zāhir) and true (bātin) essence. The chapter ends with modern developments from the late nineteenth century, where formal correctness and obedience to the Sunnah were prioritized and sociopolitical aspects affected mainly congregational prayers. The author also discusses new interpretations of human authority structures; the imam himself a subject of the laws of prayer; and the political thought regarding prayer by Hasan al-Banna, Muhammad Baqir al-Sadr, Sayyid Qutb, al-Mawdudi, and Yusuf al-Qaradawi.

Chapter 4, "The Community at Prayer," focuses on the congregational prayer, prayer leadership (imāmah), and the religious community's boundaries. The value of congregational prayer for Sunnis and Shi'as are elaborated. Legal considerations regarding Friday prayers and praying for rulers (p. 132) are reviewed. The hadith quoted by al-Tabarani urging the believers not to curse the rulers would have fitted better in the section about cursing the Companions (p. 147). The difference of attitude toward Friday prayers between Sunnis and Shi' as are detailed, including the religious legitimacy of rulers or of the prayers led by a jurist functioning as the Twelfth Imam's representative during the Greater Occultation. The hierarchy of eligibility for prayer leadership is presented. The modern development of acknowledging the validity of prayer behind a leader of another legal school (i.e., across sectarian lines to eliminate divisive commitments to the individual schools) is contrasted to the medieval view. Popular innovations (bid'ah), such as the wishes (raghä'ib) prayer during holy times (e.g., the eve of first Friday of Rajab [niş Sha $b \bar{a} n]$ ) are mentioned.

In the fifth and final chapter, "Women and Prayer," which will be of particular interest to social and gender historians, the gender neutrality of prayer as an obligation is demonstrated and the purity laws affecting women's ability to pray at specific times (e.g., menstruation and after childbirth) are cited. A lengthy section (pp. 180-90) presents views - contrary to mainstream ones arguing that a woman can lead a mixed prayer, such as those of the Shafi' $\mathrm{i}$ jurists Abu Thawr (d. 240/845) and al-Muzani (d. 246/878). Ibn Jarir al-Tabari, as well as a number of Hanbalis, opine that a woman can lead the tarāwi h prayers if no man is available or if she is the better reciter. Al-Mawardi writes 
that this is permissible if the female imam stands behind the men. The chapter further discusses women's access to mosques, their knowledge and mastery of prayer, and their instruction in prayer (p. 214). Al-Qaradawi's observation that no specific authoritative text forbids a woman to lead prayers is very interesting and important.

While discussing that a woman should clap and not talk in the mosque, the incident cited in Tafsìr Ibn Kathìr could have been noted: A woman challenged 'Umar ibn al-Khattab on the Prophet's pulpit discussing dowry ( $\mathrm{mahr}$ ) and 'Umar admitted his mistake. This chapter is very informative and makes the reader look forward to her latest book, which builds on this chapter: Women in the Mosque: A History of Legal Thought and Social Practice (New York: Columbia University Press, 2014).

The two-page conclusion closes the circle opened with the introduction that politics and gender versus spirituality and contemplation prove to be interdependent. The extensive use of brackets to add more information that should be in footnotes detracts from the flow of reading. If prayer was transliterated as salät and intimate conversation as munājāt, then niya should have been niyāt throughout.

This thoroughly researched book cites a wide range of sources from Islamic thought, which makes it of interest to students and scholars alike. Katz uses different sectarian opinions, such as those of the Isma'ilis, Mu'tazilah, Twelver Shi'ah, and Sufi scholars, and also quotes the Brethren of Purity (pp. 105, 112) and philosophers like Ibn Sina (pp. 112, 114), even if the main focus is on Sunni scholarship, thereby enriching the book and rounding off the topic in a well-balanced way.

The book is a suitable textbook for Islamic studies and is enjoyable due to her insertion of humorous expressions that appeal to students, even if they are slang. For example, Satan is cut down to size by God (p. 16), mobile phone apps sounds the adhān (p. 22), Ibn Rushd makes pithy observations (p. 28), and prayer is a predestined activity that will occur willy-nilly (p. 41). The book is definitely a concise yet comprehensive reference. 